\title{
Re-Imagining Tradition: Identity and Depictions of Ireland in Anne Enright's The Green Road
}

\section{Genoveffa Giambona}

\section{(2) OpenEdition \\ 1 Journals}

\section{Electronic version}

URL: https://journals.openedition.org/etudesirlandaises/10227

DOI: 10.4000/etudesirlandaises. 10227

ISSN: 2259-8863

\section{Publisher}

Presses universitaires de Caen

\section{Printed version}

Date of publication: 31 December 2020

Number of pages: 129-147

ISBN: 978-2-84133-996-9

ISSN: 0183-973X

\section{Electronic reference}

Genoveffa Giambona, "Re-Imagining Tradition: Identity and Depictions of Ireland in Anne Enright's The Green Road", Études irlandaises [Online], 45-2 | 2020, Online since 31 December 2020, connection on 14 November 2022. URL: http://journals.openedition.org/etudesirlandaises/10227 ; DOI: https://doi.org/ 10.4000/etudesirlandaises. 10227

\section{cc) (1) (ㅇ)}

Creative Commons - Attribution-NonCommercial-ShareAlike 4.0 International - CC BY-NC-SA 4.0 https://creativecommons.org/licenses/by-nc-sa/4.0/ 


\title{
Re-Imagining Tradition: Identity and Depictions of Ireland in Anne Enright's The Green Road*
}

\begin{abstract}
Despite attempts to label her a postnationalist writer, Anne Enright's fiction is rooted in the Irish landscape geographically, psychologically and emotionally. Enright reimagines traditional places and charges them with new symbolic value. In The Green Road Enright uses a number of narrative techniques to question given notions of identity, both individual and collective. A postcolonial identity comes through in the novel and is mirrored by its narrative structure. This article will explore how non-linear narrative, interspersed with gaps in narrative continuity and memory, is a way of reimagining, rather than transcending, questions of nation and identity. It also sets out to analyse narrative strategies and depictions of Ireland and Irishness in the novel. This article will also look at how economy and monetary elements are embedded in the narrative and at how they might be seen as part of an attempt to describe Ireland and Irish identity.
\end{abstract}

Keywords: Anne Enright, The Green Road, identity, postcolonial, postnational.

Résumé: En dépit des tentatives visant à la qualifier d'écrivain "postnationaliste», la fiction d'Anne Enright s'enracine dans le paysage irlandais de manière géographique, psychologique et émotionnelle. Enright réinvente les lieux traditionnels et leur confère une nouvelle valeur symbolique. Dans The Green Road, Enright utilise un certain nombre de techniques narratives pour remettre en question des notions identitaires, individuelles et collectives. Une identité postcoloniale transparaît dans le roman et se reflète dans sa structure narrative. Cet article explorera comment la narration non linéaire, entrecoupée de lacunes dans la continuité narrative et la mémoire, est un moyen de réinventer les questions de nation et d'identité plutôt que de les transcender. Il se propose également d'analyser les stratégies narratives et les représentations de l'Irlande et de l'irlandicité dans le roman. Cet article examinera également la manière dont les éléments économiques et monétaires sont incorporés dans le récit et comment ils pourraient être considérés comme faisant partie d'une tentative de description de l'Irlande et de l'identité irlandaise.

Mots clés: Anne Enright, The Green Road, identité, postcolonial, postnational.

* I would like to thank Prof. Steven Matthews for his guidance, suggestions, productive discussions, invaluable feedback, as well as for his support and encouragement at each and every step in the development of this article. 


\section{Introduction}

Anne Enright has secured a high status within Irish literature. Her work has been both commercially well received and highly critically acclaimed. Despite repeated attempts to label her a postnationalist writer, Anne Enright's "incisive fictional engagement with contemporary Ireland" proves that her body of work is deeply rooted in the Irish landscape, both geographically and, even more so, psychologically and emotionally ${ }^{1}$. The label postnational ignores that Enright is writing from well within Ireland, through her engagement with tradition, the nation and with what it means to be Irish today. Hence, although parts of the novel, such as, for example, the themes of globalisation and the Celtic Tiger, seem to speak to the postnational agenda which sees questions of "nation" and history as exhausted tropes, there is also a strong pull towards tradition, as exemplified by the Green Road itself ${ }^{2}$.

Although when asked about the importance of Irishness to her work, Enright seems to suggest that it is no longer a central concern for the writers of her generation, it is undeniable that she continues to revisit the usual sites of Irishness, particularly the historical past, representations of womanhood, collective memory, Catholicism, and that, in her fiction, the local landscape and cityscape are prominent ${ }^{3}$. However, these are not just geographical places, but they are reimagined, given new meaning so as to become symbols of the nation in more ways than one. Geography and landscape speak of the impact of that symbolism

1. Claire Bracken, Susan Cahill, "Introduction”, in Anne Enright, Claire Bracken, Susan Cahill (eds.), Dublin, Irish Academic Press (Irish Writers in Their Time), 2011, p. 1. For a discussion of Anne Enright and postnationalism, see Heidi Hansson, "Anne Enright and Postnationalism in the Contemporary Irish Novel”, in Irish Literature since 1990, Scott Brewster, Michael Parker (eds.), Manchester, Manchester University Press, 2009, p. 216-229; Colm Tóibín, “Introduction”, in The Penguin Book of Irish Fiction, Colm Tóibín (ed.), London, Penguin, 1999, p. xxxiii; Ana-Karina Schneider, "Postnationalism, Postfeminism, and Other 'Posts' in Anne Enright's Fiction", Studies in the Novel, vol. 50, no. 3, 2018, p. 400-418.

2. The Green Road is an actual place in County Clare, north of Kilkee above the Flaggy Shore. It is a place Anne Enright knows well as back in 2012 she and her family "rented a house [...] there and could look out the window to the Aran Islands and up to Galway. I went out every day for a walk up the Green Road. The Green Road is literally that - where the tarmac road stops and it's unpaved. It's in The Burren - a distinctive landscape of limestone with these lovely little wildflowers growing in the crevices and a few herds of goats in the heather scrub. I was writing about an Irishman in Africa while I was in County Clare. When I came back to Dublin, I wrote about County Clare" ("My Coast: Anne Enright", Coast, on line: https://www.coastmagazine. co.uk/content/my-coast-anne-enright). Enright was well aware that this road is iconic and the symbol of "a wild and beautiful part of the world. Yeats, Synge and Lady Gregory all wrote about the islands; Heaney and, especially, Michael Longley also about the Flaggy Shore. It is an iconic landscape of the Irish national revival" (Anne Enright, "A Return to the Western Shore: Anne Enright on Yielding to the Irish Tradition”, The Guardian, 9 May 2015). It seems then that, in the novel, the Green Road itself might work as a metaphor for connecting past and present.

3. Anne Enright interviewed by Caitriona Moloney, in Irish Women Writers Speak Out: Voices from the Field, Caitriona Moloney, Helen Thompson (eds.), Syracuse, Syracuse University Press, 2003, p. 61 . 
on the psyche of the collective. Consequently, although some aspects of Anne Enright's fiction appear to reflect globalising themes, it nonetheless remains rooted in nationhood and Irishness. The Green Road is a good example of this. Besides, the fractured structure of the novel can be seen as a formal strategy to reflect "the disruptive and multifaceted condition of Ireland and the Irish" 4

The impact of globalisation and internationalisation, and the meaning and relevance of locality are all interrogated in The Green Road. Notwithstanding that the novel is within a newly created tradition of the Irish literary response to these themes, it also seems to indicate a propensity towards a dialogue between local and global, rather than the supremacy of one over the other. Enright is not trying to transcend the nation as an idea, rather she wants to reshape and reimagine it in order to understand what it means to be Irish in today's changed and changing landscape and, at the same time, to make notions of Irishness more inclusive, without any nostalgia for the old national tropes. Still, at the end, The Green Road implies that the local cannot be forgotten in favour of the global and that the former has relevance still in shaping identities. A transnational perspective is thus mitigated by a representation of both continuities and discontinuities in Irish history with an implication that both must be dealt with and incorporated.

This article will explore how a non-linear narrative, interspersed with gaps both in terms of time and memory, is a way of reimagining notions of time, place and identity. It also sets out to analyse narrative strategies and depictions of Ireland and Irishness in the novel, showing how the "difficult balancing act between returning and rewriting; between rejection and translation" that Elke D'hoker sees as typical of Enright's earlier novel The Wig My Father Wore (1995), is a defining characteristic of The Green Road as well ${ }^{5}$. This paper will also look at how the economy and monetary elements are embedded in the narrative, and how they might be seen as part of an attempt to describe Ireland and Irish identity, especially in relation to womanhood.

\section{Setting the scene}

The Green Road (2015) spans twenty-five years in the life of the Madigan family, originally from County Clare, where the family matriarch, Rosaleen, and one of her children, Constance, still reside. It portrays an Ireland awash with Celtic Tiger money but, like the characters, still in search of itself. Despite its geographical setting being wider than in any of Enright's previous novels, the book ultimately starts and ends in and with Ireland, confirming Enright's focus on the contemporary nation.

4. Margarita Estévez-Saá, “A Map of Things Known and Lost in Anne Enright's The Green Road”, Estudios Irlandeses, no. 11, 2016, p. 45.

5. Elke D’hoker, "Reclaiming Feminine Identities: Anne Enright's The Wig My Father Wore", in Irish Literature, Feminist Perspectives, Patricia Coughlan, Tina O'Toole (eds.), Dublin, Carysfort Press Book, 2008, p. 186. 
Ireland after the Celtic Tiger, as figured in the book, might appear to have become a global country more or less like others. It might have seemed that rural Ireland as we knew it, with all its symbolic potential, might have disappeared. However, the opening of the novel looks as if Anne Enright has stepped into the Roscommon/Leitrim setting of John McGahern's most famous novels. It is then interesting that the rural background of the opening scenes is left behind in the second "episode" of The Green Road before returning to it in disturbing ways towards the end. It confirms the impression that the novel traces a shift in Ireland: from rural to global and, ultimately, back to rural.

As mentioned, the novel is centred around the Madigan family - Rosaleen, the mother who displays "unmotherly" characteristics, and Constance, Dan, Emmet and Hannah, her children ${ }^{6}$. The first part of the book, called "Leaving", introduces the four Madigan siblings and, at the same time, moves the family through the years, from 1980 to 2005. Two of the siblings, Dan and Emmet, have left Ireland thus reflecting the Irish diaspora of the late $20^{\text {th }}$ century ${ }^{7}$. The second half of the book, called "Coming Home", shows the Madigans gathering together for one final Christmas, as Rosaleen announces she is planning to sell the house. A lot of the domestic action happens against the background of the Green Road, a place in Ireland steeped in history and symbolism, thus firmly placing the novel at the heart of the nation. Although a postnational reading would say this stands as a symbol, a vector that reaches out from the heart of Ireland to the outside, via the Atlantic, the road is also a symbol of Gaelic Ireland, of tradition. Although it goes towards the ocean, in the book it also takes back to an old famine cottage in Boolavaun. This going outwards to go back in is also reflected in the titles of the two sections: "Leaving" and "Coming Back".

It is possible that, with reference to assimilating past tradition, with the use of the word "Leaving" Enright is referring to a narrative based on monolithic ideals and ideas of Irishness put forward and enforced by post-independence nationalism. In post-1922 Ireland, the fathers of the Free State promoted an Irish identity that was exclusively synonymous with the teachings of the Catholic Church, that only saw rural Ireland as the real Ireland, and that asserted the family, as seen by the Church, as the basic nucleus of society. The outcome was that "postrevolutionary Irish society was obscurantist, inward-turning, economically and

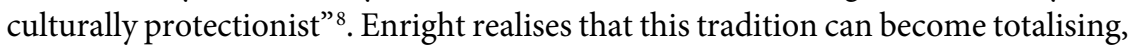
leading to the same sort of stereotyping as the colonial narrative. For this reason,

6. Anne Enright, The Green Road, London, Penguin, 2005 (page numbers between brackets refer to this edition).

7. Maria Amor Barros-del Río, “Fragmentation and Vulnerability in Anne Enright's The Green Road (2015): Collateral Casualties of the Celtic Tiger in Ireland", International Journal of English Studies, vol. 18, no. 1, 2018, p. 37.

8. Neil Corcoran, After Yeats and Joyce. Reading Modern Irish Literature, Oxford, Oxford University Press, 1997, p. 58. 
it needs resisting and dismantling ${ }^{9}$. This act of dismantling emerges clearly when it comes to female identity.

In Ireland, nationalism and the Church imposed an ideal of femininity that had to aspire to the idealised image of the Virgin Mary, symbolising obedient womanhood and pious chastity. The image of Irish women was modelled on the nationalist narrative that saw Ireland as mother and the nation as family. As a consequence, the private sphere became associated with the nation-as-family as opposed to the foreign British colonial power. This explains how the figure of Mother Ireland is a sign of the complex overlapping between the public and private spheres ${ }^{10}$. Rigidly gendered roles, seen often in postcolonial nations, can also be seen in Ireland, with some scholars identifying the oppression of women as part of a typical postcolonial gender ideology ${ }^{11}$. As far as Irish female identity is concerned, Enright has remarked that

All beliefs, nearly all kinds of national and religious belief [involved] women staying at home $[\ldots]$ so that is part of the deconstructive project $[\ldots]$ when I started off $[\ldots]$ I thought it was part of my job to say things that Irish women had not said previously ${ }^{12}$.

It appears that Enright has set herself a conscious task of dismantling stereotypical representations of Irish womanhood to give women a voice and, hence, agency.

Going back to the tension between resisting tradition and being rooted in the local, Enright also appears to say that her being influenced by this tradition cannot be helped either ${ }^{13}$. It thus appears that the novelist is complicating, reworking and

9. In the immediate post-independence period, monolithic representations of the nation were also encouraged, or enforced, in literary outputs. According to Rose Atfield, "It is [...] essential to recognise that when considering postcolonialism in Irish literature, it is not only the historical national colonialism of Ireland by England which is challenged but the 'internal' colonialism created by $[\ldots]$ the Irish social and literary establishment" (Rose Atfield, "Postcolonialism in the Poetry of Mary Dorcey”, Postcolonial Text, vol. 3, no. 3. 2007, p. 1, on line: https://www.postcolonial.org/ index.php/pct/article/view/707). This is part of the totalising tradition Anne Enright is trying to resist and dismantle.

10. Clair Wills, "Women, Domesticity and the Family: Recent Feminist Work in Irish Cultural Studies", Cultural Studies, vol. 15, no. 1, 2001, p. 38.

11. See Maryann Valiulis, "Power, Gender, and Identity in the Irish Free State", Journal of Women's History, vol. 6, no. 4/vol. 7, no. 1, 1994-1995, p. 117-136; for a discussion on postcolonial gender ideology see Declan Kiberd, Inventing Ireland: The Literature of a Modern Nation, London, Vintage, 1996; Gerry Smyth, The Novel and the Nation: Studies in the New Irish Fiction, London, Pluto Press, 1997; Michael Pierse, Writing Ireland's Working Class. Dublin After O'Casey, Basingstoke, Palgrave Macmillan, 2011; Gerardine Meaney, Sex and Nation. Women in Irish Culture and Politics, Dublin, Attic Press, 1991; Heather Ingman, Twentieth-century Fiction by Irish Women: Nation and Gender, Aldershot, Ashgate, 2007, p. 7.

12. Claire Bracken, Susan Cahill, "An Interview with Anne Enright, August 2009”, in Anne Enright, p. 21-22.

13. Enright herself states: “I don't write about Ireland so much as from Ireland. I am keenly aware of the Irish tradition and I'm very happy to take what I can from it, but it's also quite important to push against it. We're all helplessly local writers" (quoted in Miranda Popkey, "Anne Enright on The Forgotten Waltz", The Paris Review, 25 October 2011, on line: https://www.theparisreview. org/blog/2011/10/25/anne-enright-on-the-forgotten-waltz). 
reimagining nationalist ideas and ideals. Such ideals cannot be ignored but, at the same time, they need updating and expanding in order to be more representative of the contemporary nation. It is legitimate, then, to see how concepts of Ireland and Irishness are explored in Enright's fiction.

Declan Kiberd sees the Irish as "the first modern people to decolonize in the twentieth century" ${ }^{14}$. For Kiberd, this means that, besides the political and social adjustments required by a decolonising process, writers in Ireland have also had to come to terms with an experience of cultural decolonisation, deanglicisation and repossession. Moreover, Eóin Flannery argues that "the advent of an Irish franchise of postcolonial studies" is necessary to a thorough understanding of Irish culture and literature because Irish national identity was built upon the "imperial and anti-imperial experience across borders and within a protracted historical continuum" 15 . Although an Irish "franchise" that feeds upon local history and traditions can be seen as exclusive to Ireland, in order to resonate with a wide audience, it also needs to place itself in the context of wider literary movements.

So, although in much of recent Irish fiction, including the Enright novel being discussed here, there seems to be insecurity and a quest for the real self on the characters' part, this can be linked back to a quest for narrative resistance and reappropriation in Ireland, rather than being a general postmodern, or postnational, influence. This is, as Gerry Smyth tells us, both a "left over from colonial times" and the outcome of cultural resistance that challenges "colonialism's reality [...] linearity, centredness, coherence, a metanarrative location from which to judge the action of the story" to replace them with experiences of confusion, displacement, and alienation which more closely represent the reality of the colonial subject ${ }^{16}$. This can be seen as a way to re-examine the past from different perspectives; or, as Elleke Boehmer puts it, besides political reappropriation, "decolonization demanded symbolic overhaul, a reshaping of dominant meaning" ${ }^{17}$. So, culture is an important site of decolonisation ${ }^{18}$. As we will see, fragmentation, confusion and alienation are a hallmark of The Green Road. If we take into account that Gerry Smyth perceives "the novel and the nation to be closely linked" we can then infer that in Irish novels we can see the "making of the nation" and that literary culture and development of national identity are intimately connected ${ }^{19}$. Again, as we will see, the nation becomes a narrative construct, with traditional tropes reinvented and reconstructed.

In this light, Ireland's colonial and postcolonial past becomes a useful lens through which to examine contemporary Irish culture and literature, especially fiction where the female subject seems to take upon herself the processing of the

14. Declan Kiberd, Inventing Ireland..., p. 5.

15. Eóin Flannery, "Irish Cultural Studies and Postcolonial Theory", Postcolonial Text, vol. 3, no. 3, 2007, p. 1, on line: https://www.postcolonial.org/index.php/pct/article/view/814.

16. Gerry Smyth, The Novel and the Nation..., p. 23.

17. Elleke Boehmer, Colonial and Postcolonial Literature, Oxford, Oxford University Press, 1995, p. 3. In this novel, the perspectives are literally broken into five, one for each subject of the story.

18. Ania Loomba, Colonialism/Postcolonialism, London, Routledge, 1998, p. 41.

19. Gerry Smyth, The Novel and the Nation..., p. 18. 
past. The past in question can be that of the individual but representative of the collective. Moreover, given all of the above, I believe that a postcolonial legacy, both financial and psychological, is at play in these depictions rather than a postnational one. After all, it would be incorrect to assume that postnationalism is merely what follows the project of post-independence nationalism, or to label as postnational all reactions against nationalism and conclude that any discourse about globalisation and economic liberalism in Ireland is automatically postnational ${ }^{20}$.

If it is true that a country's "struggle for self-definition is conducted within language", then manipulations of and experimentations with language and form, can be seen as further evidence of an effort to build a national literature ${ }^{21}$. For postcolonial writers the linguistic mechanisms of imperialism were not adequate and "therefore new forms, or radically reimagined forms, are necessitated", especially in a situation where the language of the postcolonial writer is the same as the language in which the colonial narrative was written ${ }^{22}$. New narrative forms give the same language new power, especially when interspersed with the autochthonous language. The issue of how language has been manipulated and reappropriated surfaces especially in The Green Road, a novel where the writer uses more Gaelic words and sentences than previously, where modern characters are created from traditional ballads, and where iconic places are charged with symbolism which is mirrored by the individual. As mentioned, if national identities are also an outcome of narrative constructs, narrative and the choice of specific strategies play a big role in dismantling, reinventing and rebuilding collective identities.

This juxtaposition between collective and individual is particularly evident in the use of the family as Enright's main locus of interest. As in post-independence Ireland the rural and the family had become two of the main identifiers of Irishness and the nation, it is legitimate to conclude that the dissection of family dynamics, in a rural setting, can be seen as the analysis of a nation and its children ${ }^{23}$. This is especially so when the family's matriarch has clear associations with the figure of Mother Ireland. The Green Road makes then a good case to study when considering recent strategies evolved in Irish fiction as, firstly, it intertwines the personal and the national, and, secondly, in the novel Enright uses a number of narrative techniques to question given notions of identity, both individual and collective. Specifically, Enright seems to play with questions of Irish female identity in relation to myths in Irish society that are a legacy of the country's colonial and postcolonial history. A complex, non-linear postcolonial identity, as referred to above, comes through in the novel and is mirrored by its narrative structure.

20. Ana-Karina Schneider, “Postnationalism, Postfeminism...”, p. 404.

21. Declan Kiberd, Inventing Ireland..., p. 11.

22. Eóin Flannery, Ireland and Postcolonial Studies. Theory, Discourse, Utopia, Basingstoke, Palgrave Macmillan, 2009, p. 79.

23. Declan Kiberd, After Ireland. Writing from Beckett to the Present, London, Head of Zeus, 2017; Declan Kiberd, Inventing Ireland...; Gerry Smyth, "Irish National Identity after the Celtic Tiger", Estudios Irlandeses, no. 7, 2012, p. 132-137; Gerry Smyth, The Novel and the Nation... 


\section{The Green Road}

A return to the past in order to confront it seems to be a common thread in recent Irish fiction and this seems to be the case as well with Anne Enright's The Green Road. This is a novel about families, and family dynamics, which is told through a whole family by means of making each family member the subject of a chapter. The novel moves between the five surviving members of the Madigan family: the matriarch, Rosaleen, and her children, Dan, Emmet, Constance and Hanna. We have a third-person narrator which occasionally slips into a familial "we" and that always remains anonymous. The plot revolves around a reunion, namely the Madigans coming together for Christmas for the first time in years ${ }^{24}$. Although the novel looks back at several specific moments in the past lives of each family member, the main events, namely the reunion and its fallouts, are in the mid-2000s, when Rosaleen is thinking of selling her house to cash in on the Irish property boom $^{25}$. Consequently, this is the Madigans' last Christmas in the family home. Of the children, only the aptly named Constance has remained in their hometown in County Clare. The other three have moved away - Dan to New York and then Canada, Emmet has been travelling around the world working for charities in famine-stricken Third-World countries, whilst Hanna has been chasing an acting career in Dublin, "making it a mosaic of five people in three continents, an allegory of the diaspora of the Irish in the $20^{\text {th }}$ century" ${ }^{26}$. However, the Green Road seems to work as a metaphor for moving backwards and forwards for the family. The travelling metaphor could also be applied to Irish history or, as mentioned, symbolise a return to Ireland's roots. Moreover, the road itself serves as a vector for moving along and forward, or backward, and gives the idea of moving between different parts of the book. Unsurprisingly, the Green Road, the physical road, which is a symbol for traditional Ireland, becomes a vector not just for the family and the story, but for Ireland opening up to the wider world as well. This is the road

[...] that went across the Burren, high above the beach at Fanore, and this was the most beautiful road in the world [...] - famed in song and story [...]. And if you lifted your eyes from the difficulties of the path, it was always different again [...], the Atlantic surging up the distant cliffs in a tranced, silent plume of spray. (p. 15)

The image of the Green Road is one that juxtaposes a place steeped in history and the past, but also an outward-looking place that opens up to the vastness of the ocean and its possibilities, albeit unknown. Consequently, a novel which, from the

24. Given the children's opposition to the sale of the house and that the family reunion sees "each of them silently shouting that she could not take it away from them, whatever it was - their childhood, soaked into the walls of this house" (p. 239), the family get-together turns into a form of "wake" as well, into "mourning" for the loss of a piece of their family history.

25. A buoyancy in the property market as a sign of economic development is an element present in Enright's The Forgotten Waltz (2011) as well. So the economic theme linked to a changing face of Ireland is not an isolated instance in The Green Road.

26. Maria Amor Barros-del Río, "Fragmentation and Vulnerability...”, p. 37-38. 
title, would appear to be a very inward-looking one, is also one of Enright's most geographically expansive and outward-looking, one that perfectly encapsulates what we earlier called the effort of setting a dialogue between local and global by complicating, reworking and reimagining traditional ideas and ideals to make them more representative of the nation.

The Green Road is punctuated by gaps and silences, with gaps in time particularly evident in the first five chapters of the novel. As Enright herself notes "a lot of the book happens between the sections, in the silences" 27 . The opening of the novel itself, which lands us in the midst of something that is happening and gives us no context, is, in some ways, puzzling: "Later, after Hanna made some cheese on toast" (p. 3). As readers, we are left wondering what that "later" refers to, we feel that there is something that went on before that we do not know about: in other words, we already feel we are missing part of the story. From the start, the narrator captures snapshots, moments of transition, of becoming, of fluidity - it is as though we are being presented with one moment in time and we do not know what was before and what will be in the end. This also means that characters lack definition as they appear to be captured in their in-between state. But it also means that characters become "an open space, surrounded by a different future to the one [...] brought in through the door", which implies that a lack of rigid definition becomes an opportunity for reinvention (p. 60-61). This is the case, for example, with Dan, who is gay but who also has a girlfriend early in the novel, later his wife, of whom he says: "I love her. I have always loved her. And I fucked her willingly. And none of that is a lie" (p. 68). It is then clear that there is not one single truth, there are evolving and multiple layers of truths. Dan is also described as a man "who was discarding his former self before he had found a new one" (p. 61). A duality of identities is also hinted at in the description of Rosaleen's father, the four children's grandfather whom

[...] people said [...] was a saint - a saint, they said - to the townspeople who knocked him up at all hours for a child with whooping cough or an old lady crazed by the pain of her kidney stones. (p. 22)

The repetition of "said" seems to mimic the oral stories passed from one villager to the other. This hint to oral tradition is interesting in a context where the narrative breaks the boundaries of linearity. According to Edward Palmer Thompson "Oral evidence, by transforming the 'objects' of study into 'subjects', makes for history, which is not just richer [...] but truer" ${ }^{28}$. This is particularly relevant in the context of narrative strategies that are trying to interrogate the past. Moreover, it seems to contradict theories that Enright rejects Irish storytelling traditions and myths, as

27. “Anne Enright Talks about The Green Road", Open Book, BBC 4, 10 May 2015, on line: https:// www.bbc.co.uk/sounds/play/b05tbwsg.

28. Edward Palmer Thompson, The Making of the English Working Class, Harmondsworth, Penguin, 1963, p. 90. 
shown by the choice of the Green Road itself as the vector along which the novel moves $^{29}$. Going back to Hanna :

As far as [she] could tell, old John Considine was a saint to everyone except the people who did not like him, which was half the town [...] and she did not know why that might be. (p. 22)

It is then all about perspective and individual perceptions. Real and not-real are encapsulated in the same person, two sides of the same coin. This is again the case when we read that "Her [Hanna's] knowledge of him [Dan] came from two directions and met in the human being sitting at the table" (p. 217). It is as if two conflicting versions merge to give life to something new and independent of them.

We see the same imagery of opposites that meet to form something new just when we read about Constance and Dan

[...] on the beach in Lahinch coming around a headland to find something unexpected. And the thing they found was the river Inagh as it ran across the sands into the sea. Sweet water into salt $[\ldots]$ rainwater into seawater, you could taste where they met and mingled, and no way to tell if all this was good or bad [...] if it was corruption or return. (p. 198)

The above quotation speaks of indefinability, of hybrid formation, of half formed things that cannot be fully described but that still take their own shape. Facts become unclear, starting with Rosaleen who, according to Emmet, sees "truth [...] [as] a problem [...] facts were an irrelevance, or an accusation" (p. 214). As facts are irrelevant, it is fitting that the narrative is neither linear nor clear. However, the narrator makes us repeatedly aware that they do not know all the facts, that they are working on some assumptions. For example, we are told, through the characters, that "it wasn't easy to join the dots" (p. 146); or that they "stay [...] between things" (p. 184). So, the narrative as a whole conveys an inescapable sense of indeterminacy. Moreover, the character at the centre of Chapter I is Hanna as a child: choosing to start with a child might be a warning light that we will not be able to make sense of some things, just as a child cannot make sense of a lot of events in an adult world ${ }^{30}$. As a consequence, the different chapters work as snapshots of some events in the characters' lives ${ }^{31}$. As readers, we need to make sense of these "snapshots" of the specific moments in time the narrator chooses to include in the narrative, we need to glue them together, to fill in the silences and the gaps in order to give some coherence to the story. We are not always successful, and we

29. See Heidi Hansson, “Anne Enright and Postnationalism...”, p. 222.

30. There is a similarity here with the character of Evie in The Forgotten Waltz who does not see things, in an adult world, for what they are.

31. This structure reminds us of Joyce's Dubliners as the latter "frames, time and again, 'frozen moments in which the characters stand before us'” (Brian G. Caraher, "Reviewed Work: Essays on Joyce's 'Dubliners': A New \& Complex Sensation, edited by Oona Frawley”, James Joyce Quarterly, vol. $42 / 43$, no. $1 / 4,2004$, p. 362 ). 
are required to make a lot of assumptions to compensate for the missing links. Fragmentation, indeterminacy, fluidity are all narrative tools aimed, as we said earlier, at debunking and defying linearity. They counter-balance fixed identities and dismantle stereotypes, a way to push back against colonialism and, as we shall see later, post-independence nationalism monolithic, linear representations.

Hence, in The Green Road there is a dual narrative style which flows internally and externally to the characters. We have this duality of imagined real and true real. This concept is introduced early in the novel, for example in the following exchange between Emmet and Dan about the latter's vocation for priesthood

Later, that evening, Emmet sneered at him. "You don't actually believe [...]. You just think you do". [...] "And what is the difference again?" And so, it became real. (p. 26)

This duality also leads to the ambivalence between what is and what appears to be, as in the case of the young Hanna visit to the theatre:

The darkness of the theatre was a new kind of darkness for Hanna. [...] it was the darkness between people: between Isabelle and Dan, between Dan and the priests. It was the darkness of sleep, just before the dream. [...] He [the actor] was very real, he was as real as the spittle that flew from his mouth, though the words that came out of him were not. (p. 29)

This quote seems to directly speak about the sense of opacity that pervades the novel and sums up several of its themes: the darkness can be symbolic of the gaps in the narrative; there is an insight into the tension between real and dream, so between what is real and what appears to be real but remains unexplained and, like dreams, can be invested with symbolic value.

To add to this sense of indeterminacy, there is a sense of mystery that runs all through the novel, a sense of impalpable guilt and things unsaid, as with "Rosaleen [who] was afraid it was all her fault [...] all the things that were unsayable: failure, money, sex, drink" (p. 224). This sense of the unsayable might explain the gaps in the narrative. These gaps, besides the temporal ones, also apply to characters, in the sense that they keep appearing into and disappearing out of the narrative. Dan for example, an emotionally dry individual, is quite a mysterious character who "disappears" from the gay community in New York to reappear next in Canada, without us being told how he got there or what has happened in between. We know he is a spoilt priest, but it is never explained how he came to be so. Or Greg who appears to be dead and then reappears at the end of the novel, with no explanation whatsoever of what happened. Other characters disappear from the narrative even without being in it fully first, such as Isabelle, Dan's wife. Moreover, the fractured structure of the novel can be seen in the first part, "Leaving". This section is made up of five chapters each devoted to one of the children and to Rosaleen; yet it can almost be seen as five isolated, self-sufficient short stories. The second part, "Coming Back", is not less fragmented: this fragmentation culminates in the chaotic family Christmas get-together. 
The Green Road's opacity is also symbolised by the fact that the narrator's identity is never disclosed: the narrator is part of an indefinite "we": "We had been, for those hours on the dark mountainside, a force. A family" (p. 292); or:

We can assume, of course, that Dan went back to his melancholy little apartment and his brave wife-to-be $[\ldots]$ she was nice $[\ldots]$ it takes a quality woman to keep a guy like Dan straight $[\ldots]$ or not $[\ldots]$ who is to judge, Meine Damen und Herrrren? (p. 59)

The use of the word "assume", and the whole passage, imply that the narrators, whoever they are, is not so omniscient. Moreover, by explicitly admitting that s/he does not know everything, the narrator is also admitting that there is a certain amount of uncertainty in their story and that it is up to us as readers to make up our own minds about the events. This form of "emerging" meaning counter-balances the narratives imposed from above we mentioned earlier.

Therefore, uncertainty and doubt are the leitmotivs that run through this novel. It is as though we are always expecting some resolutive fact to be revealed and resolve the uncertainty. However, no backstory surfaces. "It's like there's some secret [...] but there just isn't" Hanna says at one stage in the novel (p. 243). When Rosaleen wonders, "Where did it begin? [...] It was more a cadence than a question, it was another scrap in a life full of scraps, some of them beautiful", we are not even sure what "it" is (p. 259). Actually, there is no story either, not in the traditional sense anyway. There then comes the realisation that "there was no path. She [Hanna] thought there would be a path [...] but there was no path. No trajectory" (p. 193) ${ }^{32}$. This works as another warning light to the reader not to expect any guidance from the narrator in joining the dots of the story. The characters then seem to fall in the gaps of the narrative: "Because there were gaps between things, and this frightened her. This is where Rosaleen was now. She had fallen into the gap" (p. 266). This is something that we can link back to what Enright stated about a lot of the novel happening in the gaps.

In this light, it is very fitting that it is Rosaleen herself who comes to symbolise the undefined, the split identities, when, while searching for her, her children all call her by a different name

Mama... Rosaleen... Mam... Mammy... the comedy of it was not lost on them, the fact that each of her children was calling out to a different woman. They did not know who she was - their mother, Rosaleen Madigan - and they did not have to know. (p. 283-284)

If we accept, as argued below, that Rosaleen can be seen as a symbol for Ireland, then it is very clear that she can also be interpreted as an image of an Ireland whose children are in the process of figuring her out. She is, in fact, what each character makes of her, a projection they do not "have to know" or agree upon.

32. The only path, the only trajectory seems to be the Green Road. So there is a paradox here: despite the statements about gaps, lack of paths and trajectory in the present, the whole book is centred, from its title, around a road, a sign of clear trajectory, which represents the past. It is then as though something has become disconnected between Irish past and present. 
Rosaleen is also depicted as having little to do with normally accepted concepts of time and temporality. We are told that she has "no idea what the proper time was" (p. 154). Yet her very name, Rosaleen, has clear nationalist connotations and associates her with the nation's past. It evokes, for example, James Clarence Mangan's patriotic poem where the Dark Rosaleen of the title stands for Ireland itself. This is a poem which the character herself quotes at one point (p. 160-161). When we first see her, she appears to be in a sort of timeless limbo, staring at a clock that "had been stopped for years, maybe five years. [...] some time after Dan went. [...] some time after her own true love Pat Madigan died" (p. 152) ${ }^{33}$. Rosaleen, or Mother Ireland, has been deserted by her men. The juxtaposition between Rosaleen and the nation recalls a more general juxtaposition: within nationalist discourse, Ireland was often represented as an abandoned mother ${ }^{34}$.

Rosaleen's association with the past is made even more explicit by her immediate association, in the narrative, with a poem that she recites to herself throughout. The poem in question is Emily Lawless's “Fontenoy 1745”, part of the poet's Wild Geese poems. The Wild Geese were Irish soldiers who served in continental European armies from the $16^{\text {th }}$ to the $18^{\text {th }}$ century. According to Enright herself

The Wild Geese were the first lost Irish generation, remnants of the defeated Irish nobility who left in 1691, seeking alliances and fighting other men's battles on the European mainland. Laments for this lost leadership were everywhere in the bardic poetry I learned in Irish class at school, with the figure of Ireland waiting for her rescue: Ireland as lost heifer, as dream, as beautiful woman or old woman, awaiting their return. [...] This was a poetry of abandonment, not of exile ${ }^{35}$.

Rosaleen feels oppressed by her own house, she wonders "why was there no one to love her" (p. 260). She is shown as the last keeper of a place that is falling "apart all around her" while she carries on reading (p. 164), where the bed above her was "ready to fall through the plaster" (p. 162). It is not surprising, then, that she is associated with a poem about abandonment, loneliness and the wait to be rescued. If we accept that Rosaleen stands for Ireland, then, her feelings of being neglected and abandoned by her own children who spend "their lives getting out of there", might be symbolic of the Irish leaving the motherland which recalls the historical issue of the Irish diaspora (p. 272). Moreover, thinking back to the earlier quote where she wonders whether her children's problems are her fault, we can infer that the failures of the Irish "children" might all be imputable to the "motherland". Nonetheless, just like the narrative, the character and "meaning" of Rosaleen are not linear or straightforward either: despite on the one hand appearing as a clear nod to a whole

33. According to Bridget English, stopped clocks are symbolic of corresponding pauses in time and, hence, of gaps in time. This is very fitting in a narrative characterised by gaps (Bridget English, Laying out the Bones. Death and Dying in the Modern Irish Novel, Syracuse, Syracuse University Press, 2017, p. 170).

34. Clair Wills, "Women, Domesticity and the Family...", p. 38.

35. Anne Enright, "A Return to the Western Shore...”. 
nationalist tradition, she nonetheless seems to be the one who wants to move on from "the stillness of [her] stopped kitchen clock" (p. 268). It sounds as if she wants to relinquish her role of preserving the past through the house. Moreover, we must bear in mind that, as mentioned, throughout the novel, Rosaleen is associated with unmotherly and suffocating characteristics, as if to highlight the overpowering overtones of the Mother Ireland discourse put forward by conservative nationalism, and to dismantle its accepted representations of womanhood. The Green Road gives a glimpse into how, through Rosaleen who is synonymous with Ireland in nationalist traditional poetry, Enright is reimagining and dismantling colonial and postcolonial conceptualisations of womanhood and the nation ${ }^{36}$.

Emily Lawless's poem strengthens the nationalist connotations of Rosaleen's name. From a $19^{\text {th }}$-century perspective, Lawless tried to challenge questions of national identity and cultural validity. Like many Anglo-Irish contemporaries, she was anxious to formulate a credible continuity for her ethnic class within the frame of an overall shared national history. Moreover, whilst never supporting Home Rule, she was at the same time critical of British attitudes towards Ireland, so that her own identity was in a way syncretic as she harboured both nationalist and unionist sympathies ${ }^{37}$. Besides, like Rosaleen who is introduced sitting silently in her kitchen, Lawless's female characters are often silent. This is the case with Grania, for example, whose frustrated silences are seen by some as embodying the plight of womankind ${ }^{38}$. According to Geraldine Meaney, Lawless's work speaks of an Irish literary history that is more heterogeneous and discontinuous than the canon indicates. Indeed, Lawless's denunciation of frustrated female silences is a denunciation of Irish women as silent historical victims, both as citizens and as writers $^{39}$. We can then see that Enright is evoking more than a mere poem when citing "Fontenoy 1745 " in The Green Road. She is possibly invoking a need for syncretism when thinking about Irishness. Besides, bearing in mind Enright's belief that whilst "traditionally, Irish writing has been about breaking silences. The biggest silence has continued to be about the real lives of women", she is bringing to the fore the plight of forgotten, silenced and / or ignored female voices, something that the gaps in her broken, discontinuous narrative seem to reflect as well ${ }^{40}$.

36. For further reading on the myth of Mother Ireland and womanhood in colonial and postcolonial Ireland, see Richard Kearney, Myth and Motherland, Derry, Field Day (A Field Day Pamphlet; 5), 1984; Catherine Nash, "Embodied Irishness: Gender, Sexuality and Irish Identity", in In Search of Ireland: A Cultural Geography, Brian Graham (ed.), London, Routledge, 1997, p. 108-127. For a discussion of reclaiming female identities, with a particular attention to The Wig My Father Wore, see Elke D’hoker, "Reclaiming Feminine Identities...”.

37. Heather Ingman, Irish Women's Fiction: From Edgeworth to Enright, Dublin, Irish Academic Press, 2013, p. 37-43.

38. See Michael O’Flynn, "Introduction" to Emily Lawless, Grania. The Story of an Island, Brighton, Victorian Secrets, 2013.

39. Geraldine Meaney, "Decadence, Degeneration and Revolting Aesthetics: The Fiction of Emily Lawless and Katherine Cecil Thurston", Colby Quarterly, vol. 36, no. 2, 2000, p. 157-175.

40. Anne Enright, quoted in Justine Jordan, "A New Irish Literary Boom: The Post-Crash Stars of Fiction”, The Guardian, 17 October 2015. 
As mentioned, in The Green Road there is a reference to the recent Irish economic situation. After an illusion of stability and "rediscovered" Irishness during the 1960s, the post-independence nationalist ideology collapsed, giving way to a new feeling of displacement and non-belonging, especially in fiction. So, in the 1990s and beyond, when Ireland was reinventing itself from a social and economic point of view thanks to the Celtic Tiger, fiction remained somewhat focused on the Irish past and a quest for identity in post-independence Ireland. In this respect, Joe Cleary observes that

It is the very nature of historical trauma that it should take a long time to disclose itself. The pain and suffering endured by one generation in one set of historical conditions is often doomed to remain silent and inarticulate, sometimes awaiting the radically altered historical conditions of a later generation before it can find terms and conditions propitious to its expression. [...] This perspective [...] suggests a sense of Irish history as trauma ${ }^{41}$.

From this perspective, The Green Road can be seen as processing the traumas and the quest for a national identity of the past in an attempt to discover and reinvent what Ireland and Irishness meant, rather than a move towards a postnational stance.

The financial boom in Ireland and the theme of the Celtic Tiger are interwoven with the narrative. We see snapshots of a country transformed when Hanna and Emmet walk into "a pub that, in their youth, smelt of wet wool and old men [and] was now a gallery of scents, like walking through the perfume department in a Duty Free" which already suggests this is not something real, but rather staged and temporary (p. 221). Therefore, we get the feeling that the economic boom of the noughties is a false promise of change when we read that

Since the money came in, Ireland depressed Emmet in a whole new way. The house prices depressed him. And the handbag thing, the latte thing, the Aren't We All Brilliant thing. (p. 206)

In fact, the whole situation makes Emmet feel that "He should go back to counselling. Ireland was wrecking his head" (p. 225) ${ }^{42}$. The newfound prosperity is seen as ephemeral, a way of lulling the Irish into thinking that they have moved away from the problems of the past, as "showing off" (p. 223) rather than a substantial change.

This tension is encapsulated in the description of the shopping trips to New York Constance and Dessie, her husband, can afford to take, rather than emigrating there. This apparent glamour is however in striking contrast with her just getting "a couple of Eileen Fisher cardigans in lilac and grey" while "she and Dessie stayed with her brother Dan on a fold-out bed in his apartment in Brooklyn" (p. 87). Interestingly,

41. Joe Cleary, Outrageous Fortune. Capital and Culture in Modern Ireland, Dublin, Field Day, 2007, p. 210.

42. It is interesting to see what power the nation has on the individual. 
the most significant episode in the novel that signals middle class prosperity in that period is Constance's trip to the supermarket for her Christmas shopping (p. 228230). Constance buys plenty of delicacies and more food than the family can possibly hope to eat, with her bill coming in at around 500 euros. In a country where the average Catholic Irish person was historically often malnourished, or the victim of famines, it might not be by chance that Enright chooses to include splashing out on unnecessary and/or exotic food as a sign of new economic prosperity.

Nonetheless, despite this new-found belief that things have changed thanks to the improved economic situation, for some of the characters "actual life [...] happened far away from here" (p. 247). Further, "Constance still liked Ireland, the way you could talk to anyone. It would not be the same in America" - Ireland, with all its downfalls, is still seen as more human and preferable to a more cosmopolitan place (p. 86). It is not by chance that this character's name is Constance. She is the only one that stays in her native county; she is the only one who, despite everything, stays close to Rosaleen and seems to really care about her; and she is the one who is represented as quietly accepting life, and Ireland, as they are. By choosing Constance, a woman, in these episodes which reflect the new Ireland of the Celtic Tiger boom, Enright maintains the intersection between the national dimension and women - even in the novel's exploration of the socio-economic state of the nation ${ }^{43}$. By describing small, personal memories, the narrative, at the same time, gives a snapshot of the social status of a nation.

Another episode in the novel that carries collective resonance, and grounds it further into Irish history and symbolism, is the one in which Rosaleen gets lost after running away from the Christmas family reunion. The empty famine cottage where Rosaleen finds shelter, the "little famine cottage" that is at the end of the Green Road, has central symbolic value (p. 273) ${ }^{44}$. The abandoned cottage speaks of imperial dispossession.

43. Besides the economic situation, Enright wants to capture specific moments in Ireland's social life, further evidence of the writer's ultimate interest in the becoming of the nation. This is the case when she talks about contraceptives, mentioning that, at a time when the pill was not readily available in Ireland, her uncle's wife "was on the pill, because they had access to the pill" (p. 5). Contraception was illegal in Ireland from 1935 until 1980, when it was legalised with several restrictions, later loosened. However, even after contraception got legalised, there still was a social stigma due to the strong anti-contraception stance of the Catholic Church. So, when reminiscing about her stint working at a pharmacy, Constance recollects that "Every customer who walked in the door came in with a look on their faces and a prescription for condoms folded four times. They came into town so their local chemist would not know" (p. 84). For a discussion on contraception, the Catholic Church and women's rights see Declan Kiberd, After Ireland..., p. 315-317.

44. The Irish Famine has great significance in Ireland's colonial history. Although regular emigration from Ireland to North America and Britain was already taking place by mid- $19^{\text {th }}$ century, it was because of the Great Famine of 1845-1849 that the Irish started emigrating in large numbers so consistently that "the tradition had become self-sustaining" (Declan Kiberd, After Ireland..., p. 103). The Famine has been seen as the event that symbolises the historic trauma Ireland underwent under, and because of, the British Empire. For example, according to Conor Carville, "it is principally through consideration of the Famine that notions of 'historical' trauma [...] make their way into Irish studies" (Conor Carville, The Ends of Ireland, Manchester, Manchester University 
Both the cottage and the Green Road are near Boolavaun, the grandmother's house that Hanna used to visit as a child, a place of mystery as well, built among

[...] grey rocks under a grey sky, and there were days when the sea was a glittering grey and your eyes could not tell if it was dusk or dawn [...] and that was the thing about Boolavaun, it was a place that made itself hard to see. (p. 16)

So Boolavaun is depicted as a ghost-like place, and if we accept it does stand for past memories, then it is as if these past memories themselves are ghost-like and hard to see. To Rosaleen, "her walk on this road [...] was the road to her youth", so a clear link to the past (p. 264). It is symbolic that Rosaleen survives when the original inhabitants very likely died because of the Famine - it seems a sign of reappropriation. As mentioned, in tune with the idea of The Green Road as a geographically open novel, the deprivation in the novel resonates beyond the Irish borders: it is seen in the section about Dan and the devastation caused in the New York gay community by AIDS; or in the relief efforts Emmet is involved with trying to help famine-stricken communities in Africa. Yet it finds its historical prompt and centre in Enright's rendering of the recent Irish past.

At the end of the novel, the past comes back into the present: figures that had disappeared, as if swallowed by the narrative, resurface and it is as if the characters try to reach out to the past to tidy up the present. This is the case, for example with Dan who gets in touch with someone he thought was dead; or Emmet who reaches out to his ex-girlfriend. By foregrounding the Green Road, Enright is foregrounding history, myths and traditions. At the same time, the road provides a platform to look into the space beyond it. Once again, going over the past provides a springboard for diving into the future. Like the Green Road, the characters are steeped into their own history, but ready to look away from it and into the future.

\section{Conclusion}

Far from going through a "postnational" phase, Ireland is rather reworking and reimagining definitions of Irishness and national identity in relation to its newfound role in a global context. The preoccupations with Ireland's role in a global setting, its emergent cosmopolitanism and the effects of a liberal economy, rather than being seen as a move away from discourses around national identity, can be seen as a representation of the challenges they pose to Ireland's emergent cultural and national identity. If we accept that narrative is a powerful tool in creating a national discourse, then this discourse is reflected in the novel we have been discussing. We have seen how, despite some suggestions that she is uninterested

Press, 2011, p. 28). Moreover, Terry Eagleton sees the Famine as the event in Ireland that "shatters space as well as time, unmaking the nation and scattering Irish history across the Globe" (Terry Eagleton, Heathcliff and the Great Hunger, London, Verso, 1995, p. 15). 
in national discourse, Enright is deeply engaged with the usual sites of Irishness, particularly the past, identity, collective and individual memory, and traditional tropes around womanhood.

In Rosaleen, Enright juxtaposes Ireland and a woman. However, this juxtaposition challenges the well-established and traditional tropes of Ireland-as-woman. The indeterminacy and non-linearity of the narrative mirror the individual's, but rather than being seen as a negative trait, they can work as a positive one, offering scope to reimagine both the individual and the collective. For example, by being so undefined Rosaleen is, nonetheless, also the one who has the most chances to change, renew and move forward as proved by her firm determination to sell the house, which stands for stillness and the past. In more ways than one, Rosaleen is the heart of The Green Road: by representing, at the same time, traditional Ireland and, through the subversion of conventional ideas of Irish womanhood, its opposite. In this sense, she confirms that Enright's way of engaging with the debate around identity offers a synthetical, rather than analytic and antithetical, approach to Irishness; that is one that proposes engagement with the emergent cosmopolitanism of Irish society and, at the same time, explores the awareness that history and tradition are indispensable to self-awareness and self-discovery, be it national or individual. She marries the local and the global rather than seeing them as antagonistic. According to Gerry Smyth,

There can be no decolonising literature, no national culture of resistance, before a prefiguring critical discourse creates a series of social and institutional spaces in which a culture and its particular effects can function and have meaning ${ }^{45}$.

As fiction becomes more flexible, starting with its own techniques, its relationship with theory might be becoming more flexible as well. In the case of The Green Road, it seems that narrative itself has become a space in which to reimagine the nation and its past, to bridge old and new Ireland, the local and the global, to become the locus of the nation. It is as if Enright is reshaping narrative by reconfiguring things through the lens of imagination - her own and the reader's - so that the rereading of the past becomes reimagining it. She is taking physical traditional Irish locations and charging them with new, symbolic meaning. Myths and legends can be used to give us roots and wings.

The Green Road works as a window into the characters' life of which we are given "episodes" not connected by place nor time. Like Joyce in Dubliners, and starting from a child's perspective as he did, Enright is giving us snapshots, moments in time in the (psychological) life of the characters. It is as if, by turning to Joyce, who at the beginning of the $20^{\text {th }}$ century wished "to forge in the smithy of [his] soul the uncreated conscience of [his] race”, Enright is trying to follow in his footsteps by,

45. Gerry Smyth, "Decolonization and Criticism: Towards a Theory of Irish Critical Discourse", in Ireland and Cultural Theory: The Mechanics of Authenticity, Colin Graham, Richard Kirkland (eds.), Basingstoke, Macmillan, 1999, p. 33. 
at the same time, reimagining Ireland from a woman's perspective and rooting it in the $21^{\text {st }}$ century ${ }^{46}$.

If "no other culture illustrates the push and pull of globalization and localization better than Irish culture", then The Green Road, as a novel, exemplifies this pull ${ }^{47}$. However, ultimately, this pull seems to be resolved with a "Coming Back" within Ireland and all that the Green Road as a physical and emotive space represents. Thus, whilst on the one hand acknowledging the need to engage with the growing cosmopolitanism of Irish society, brought about by the Celtic Tiger years, on the other Enright is deeply aware that history and tradition provide roots and are indispensable to self-understanding, be it national or individual.

Far from being postnational, then, through its individual characters, especially Rosaleen, The Green Road depicts a nation redefined in the light of both its colonial past and its present. The novel delves into the complications of an evolving nation that is taking stock of this past and comprehending how it links to the present. The individual effort of trying to move into the future by confronting the past, rather than transcending it, reflects that of the collective, and imagination mediates these encounters with the past. This negotiation between local and global, past and present reminds the reader of what Gerry Smyth perceives as the basic questions once-colonised nations are still asking themselves like:

Who am I in relation to the groups and the beliefs [...] I perceive around me? Who am I in relation to the past from which I believe myself to have emerged and the future towards which I believe myself to be moving ${ }^{48}$ ?

These basic questions, albeit in a different guise due to a changing and changed environment, are still alive and fiction remains a space where to interrogate and develop them.

Genoveffa Giambona

University of Reading

46. James Joyce, A Portrait of the Artist as a Young Man, London, Penguin Classics, 2000, p. 276.

47. Ana-Karina Schneider, "Postnationalism, Postfeminism...", p. 400.

48. Gerry Smyth, The Novel and the Nation..., p. 4. 